\title{
Allelic diversity of merozoite surface protein-1 (MSP 1) and MSP 2 genes, and clinical manifestations of Plasmodium falciparum malaria cases in Aceh, Indonesia
}

Kurnia Fitri Jamil ( $\nabla$ kurnia_jamil@unsyiah.ac.id )

Syiah Kuala University

Nandha Rizki Pratama

Eijkman Institute for Molecular Biology

Sylvia Sance Marantina

Eijkman Institute for Molecular Biology

Harapan Harapan

Universitas Syiah Kuala

Muhammad Riza Kurniawan

Universitas Syiah Kuala

Tjut Mariam Zanaria

Universitas Syiah Kuala

Jontari Hutagalung

Kementerian Kesehatan Republik Indonesia Badan Penelitian dan Pengembangan Kesehatan

Ismail E Rozi

Eijkman Institute for Molecular Biology

Puji BS Asih

Eijkman Institute for Molecular Biology

\section{Supargiyono Supargiyono}

Universitas Gadjah Mada

Din Syafruddin

Eijkman Institute for Molecular Biology

\section{Research}

Keywords: allele, malaria, MSP 1, MSP 2, P. falciparum, clinical manifestations

Posted Date: August 24th, 2020

DOI: https://doi.org/10.21203/rs.3.rs-57378/v1 
License: (c) (i) This work is licensed under a Creative Commons Attribution 4.0 International License. Read Full License

Version of Record: A version of this preprint was published at Malaria Journal on April 13th, 2021. See the published version at https://doi.org/10.1186/s12936-021-03719-w. 


\section{Abstract \\ Background}

Malaria control programme in Indonesia has successfully brought down malaria incidence in many parts of the country, including Aceh Province. Clinical manifestation of reported malaria cases in Aceh varied widely from asymptomatic, mild uncomplicated to severe and fatal complications. The present study aims to explore the allelic diversity of merozoite surface protein genes among the $P$. falciparum isolates in Aceh Province and to determine their potential correlation with the severity of malaria clinical manifestation.

\section{Methods}

Screening of over 500 malaria cases admitted to the 11 districts hospital within Aceh Province during 2013-2015, identified 90 cases of $P$. falciparum mono-infection without any co-morbidity. The subjects were clinically phenotyped and parasite DNA was extracted and Polymerase Chain Reaction (PCR) amplified for the MSP1 and MSP2 allelic subfamilies.

\section{Results}

Analysis of clinical manifestation revealed that fever-chill is the most frequent symptom. Based on WHO criteria showed 19 cases classified as severe and 71 as mild malaria. Analysis of MSP 1 gene revealed the presence of $\mathrm{K} 1$ allele subfamily in 34 subjects, MAD20 in 42 subjects, RO33 in 1 subject, and mixed allelic of K1 + MAD20 in 5 subjects, K1 + RO33 in 4 subjects, and MAD20 + RO33 in 4 subjects. Analysis of MSP 2 gene revealed 34 subjects carried the FC27 allelic subfamily, 37 subjects (carried the 3D7 and 19 subjects carried the mixed FC27+3D7. Analysis of multiplicity of infection revealed that msp2 alleles is slightly higher than MSP 1 with the mean of MOI were 2.69 and 2.27, respectively. Statistical analysis to determine the association between each clinical manifestation and MSP 1 and MSP 2 alleles revealed that liver function abnormal value was associated with the MSP 2 mixed alleles $(p<0.05$; odds ratio = $0.13 ; \mathrm{Cl} 95 \%=0.03-0.53)$. Malaria severity was associated with the mixed MSP 1 of $\mathrm{K} 1+\mathrm{RO} 33$ with severe malaria $(p<0.05$; odds ratio $=28.50 ; \mathrm{Cl} 95 \%=1.59-1532.3)$.

\section{Conclusion}

This study found a strong association between severe malaria in Aceh with subjects carrying the MSP 1 mixed alleles of $\mathrm{K} 1$ and R033. The liver function abnormal value associated with the MSP 2 mixed allelic subfamilies. Further study in different geographic areas is recommended.

\section{Background}


Malaria remains a major public health problem in Indonesia despite a success in bringing down the incidence within the last few decades. Since the implementation of the malaria elimination program in 2009 , the malaria cases in Indonesia dropped significantly from 418,439 to 261,617 and the vast majority of the cases occurred in 5 provinces of the eastern parts of country [1]. In Aceh Province, effective monitoring of the implementation of malaria elimination programme has also successfully brought down the Annual parasite incidence (API) from 0.08 in 2015 to 0.06 in 2017. The success of malaria control program relies on three main efforts; early diagnosis and prompt treatment, provision of long-lasting insecticide-treated bednet (LLINs) and insecticide residual spraying. Attempts to develop a suitable vaccine to prevent malaria continue to elude us as several vaccine candidates still fail to provide the required efficacy.

The clinical manifestation of malaria infection in human varies widely, from asymptomatic to fatal infections with cerebral or non-cerebral complications. This phenomenon is associated with factors associated with the malarial parasite, human host and environment. Studies to identify parasite factors that contribute to virulence revealed several candidates such as antimalarial drug resistance, cytoadherence, and antigenic polymorphisms [2]. Clinical manifestation of malaria is directly associated with the repeated cycle of invasion of the red blood cell (RBC) by merozoites, followed by development into schizont which end up in the rupture of the RBC and release of daughter merozoites. During the blood stage, the parasite expresses arrays of proteins and among others are merozoite surface protein 1 (MSP 1) and MSP 2. These proteins are involved in erythrocyte invasion [3] and are targeted by the immune responses [4,5], and therefore have been used as target for vaccine development. MSP 1 and MSP 2 also exhibit high polymorphisms hence play important role in identification of genetically distinct $P$. falciparum parasite sub-populations [3]. MSP 1 gene is located on chromosome 9 and contains 17 blocks of sequences [6]; block 2 is most polymorphic and is grouped into three allelic families MAD20, K1 and R033 [7]. MSP 2 gene is located on chromosome 2 composed of 5 blocks and block 3 is the most polymorphic [8]. The MSP2 alleles are grouped into two allelic families, FC27 and IC1/3D7) [9].

Many studies have explored the potential roles of MSP 1 and MSP 2 alleles in the modulation of malaria clinical manifestations. In French Guyana, study on the MSP 1 and vargenes demonstrated that MSP1 $\mathrm{K} 1$ allele and vargenes, D allele overexpression associated with severe malaria [10]. Multiple field studies have tried to characterize virulent strain of Plasmodium falciparum using genetic polymorphisms as markers. Although evidence of differences in virulence among the $P$. falciparum strains have accumulated, the virulent strains have not yet been characterized in sufficient detail to identify suitable virulence markers. The present study aims to explore the allelic diversity of merozoite surface protein genes among the $P$. falciparum isolates in Aceh Province and their potential association with the severity of clinical manifestation of malaria.

\section{Methods}

\section{Study site}


This study was conducted in eleven district hospitals in Aceh Province, Indonesia (Fig. 1). Patients admitted with initials diagnosis of malaria were screened for cases with mono infection of $P$. falciparum without any co-morbidity. At admission, thick and thin blood films were obtained using finger prick, stained with Giemsa and examined by accredited microscopists. Any subjects declared positive by microscopy will be further stated in parasite density for microliter blood as previously described. Dried blood spots were made using 3MM Whatman 3M paper (GE Healthcare, Buckinghamshire, UK) and kept in individual plastic ziplock until used.

\section{Determination of malaria severity}

Upon admission to the hospital, all subjects underwent physical examination and laboratory assays for complete blood count, thin and thick blood smear, liver and kidney function tests. History taking and consent were obtained from patients or legal guardian. Clinical manifestation of the patients was assessed and classified using the World Health Organization (WHO) criteria.

\section{Criteria for severe malaria}

Severe falciparum malaria is defined as one or more of the following [11], occurring in the absence of an identified alternative cause and in the presence of $P$. falciparum asexual parasitaemia: (a) Impaired consciousness, (b) Prostration, (c) Multiple convulsions, (d) Hypoglycaemia, (e) Renal impairment, (f) Jaundice, (g), Pulmonary oedema and (h) Significant bleeding; haematemesis or melaena.

\section{Blood collection and DNA Preparation}

Blood of the consented subjects were collected using finger prick for making thin and thick blood smears, dried blood spot on Whatman 3M filter paper (GE Healthcare, Buckinghamshire, UK) and kept in individual plastic ziplock bag.

\section{DNA extraction and polymerase chain reaction}

The parasite DNA was extracted from the filter paper using Chelex-100 ion exchanger method as described previously [12]. The DNA extract was used as template for the nested PCR using oligos that target the parasite MSP 1 and MSP 2 genes [13]. The second reaction primer set targets specific allelic families of MSP 1 (MAD20, K1 and R033) or MSP 2 (IC/3D7 and FC27). Reactions for each set of primary and nested primers were performed separately.

\section{Multiplicity of infection (MOI)}

MOls were calculated by dividing the total number of distinct MSP 1 and MSP 2 genotypes by the number of positive samples for each marker. The mean $\mathrm{MOI}$ was calculated by dividing the total number of alleles detected in both MSP 1 and MSP 2 by the total number of positive samples for both markers. Samples were considered single infected when harbouring only one allele at each of the genotyped loci. Multiclonal infections were defined as infections with more than one allele in at least one locus.

\section{Statistical analysis}


All data were collected with Epidata and analysed by R version 3.4.0. The allelic subfamily frequency of MSP 1 and MSP 2 was calculated as the proportion of the allele detected for each allelic family out of the total of alleles detected. The frequency of polyclonal infection was calculated using number of samples with more than one amplified fragment out of the total samples. The mean multiplicity of infection (MOI) was determined by dividing the total number of alleles detected in both MSP 1 and MSP 2 by the total number of positive samples for both markers. The Chi-square test was used to analyse the association of the clinical manifestations and the allelic subfamilies of the MSP 1 and MSP 2. Statistical significance was defined as $\mathrm{P}<0.05$.

\section{Results}

The study subject's recruitment flowchart and the procedures applied to subjects is shown in Fig. 1. Of the total 500 subjects admitted to the hospital with fever, 176 subjects were found positive by microscopy and 117 of which by $P$. falciparum. Further validation by PCR revealed 90 subjects with $P$. falciparum mono infection. Among the 90 study subjects, $57.7 \%$ of them were male and $42.3 \%$ were female with most subjects (46.7\%) aged between $21-30$ years old (Table 1 ).

Table 1

Characteristics of study subjects P.falciparum malaria cases

\begin{tabular}{|ll|}
\hline Variable & Overall \\
\hline Number of patients enrolled & 90 \\
\hline Age (year) & \\
\hline -Mean & $33(36 \%)$ \\
\hline -Range & $19-63$ \\
\hline Gender & \\
\hline -Male [n (\%)] & $52(58 \%)$ \\
\hline -Female [n (\%)] & $38(42 \%)$ \\
\hline Body temperature [ $₫ \mathrm{C}$, mean (SD)] & \\
\hline$<37.5 \llbracket C$ & 0 \\
\hline$\geq 37.5 \rrbracket C$ & $90(100 \%)$ \\
\hline Parasite density (/ul) & \\
\hline [mean geometric parasitemia] & $82(91 \%)$ \\
\hline$>10.000$ & $8(9 \%)$ \\
\hline$\leq 10.000$ & \\
\hline
\end{tabular}




\section{Clinical manifestation of the subjects}

The clinical manifestation, origin and laboratory profiles of each subjects is shown in Tables 2 . The commonly observed symptoms and signs includes fever with chill (100\%), dyspnoea $(75.6 \%)$ and spleen enlargement (87.8\%). Severe signs such as shock, convulsion and conscious disturbance were observed in few cases. Laboratory assays revealed anaemia in $36.8 \%$ of the subjects, abnormalities in the values of liver (63\%) and kidney (95.6\%) function, and haemoglobinuria (20\%). Of the 90 subjects examined $92 \%$ had parasite density of 10,000 parasite per microliter blood and the remaining $8 \%$ had parasite density of less than 10,000/ $\mu$ l blood. Based on WHO classification [11], 19 subjects were classified as severe malaria whereas the remaining 71 subjects were mild, uncomplicated malaria.

Table 2

Clinical manifestation and laboratory profiles in Aceh Province

\begin{tabular}{|lll|}
\hline Profile & Symptoms and Signs & Total \\
\hline Physical examination & Fever $(\geq 37.5 \rrbracket C)$ & $90\left(100^{\star}\right)$ \\
\cline { 2 - 3 } & Dyspnea & $68(75.6)$ \\
\cline { 2 - 3 } & Splenomegaly & $79(87.8)$ \\
\cline { 2 - 3 } & Convulsion & $2(2.2)$ \\
\cline { 2 - 3 } & Conscious disturbance & $4(4.4)$ \\
\cline { 2 - 3 } & Shock & $3(3.3)$ \\
& Anemia & $33(36.7)$ \\
\cline { 2 - 3 } & Abnormality in the values of liver function & $57(63.3)$ \\
\cline { 2 - 3 } & Abnormality in the values of kidney function & $86(95.6)$ \\
\cline { 2 - 3 } & Hemoglobinuria & $18(20)$ \\
\hline \multirow{2}{*}{$*$ percentage $(\%)$} & & \\
\hline
\end{tabular}

Table 3

Classification of malaria severity in Aceh based on WHO

\begin{tabular}{|llll|}
\hline Classification of malaria severity & $\mathbf{N}(\%)$ & P value & Cl 95\% \\
\hline Severe & $19(21 \%)$ & $4.223 \mathrm{e}-08$ & $0.140-0.306$ \\
Mild & $71(79 \%)$ & $4.223 \mathrm{e}-08$ & $0.694-0.860$ \\
\hline
\end{tabular}

Allelic subfamily frequency of the MSP 1 and MSP 2 genes

Allelic analysis of the MSP 1 gene revealed the existence of K1 (37.7\%), MAD20 (46.7\%), and RO33 (1.1\%) subfamily, either as single or mixed allelic subfamilies (Table 4). Analysis of the size of amplicons in 
each subfamily revealed that K1 subfamily had 3 alleles, MAD-20 had 5 alleles and R033 had 2 alleles. Allelic analysis of the MSP-2 revealed that there were two different allelic subfamilies. Of the total 90 subjects examined, the FC27 subfamily was observed in $41.4 \%$, the $3 D 7$ subfamily in $37.7 \%$ of the subjects and $21.2 \%$ of the subjects carried the mixed subfamilies of FC27 and 3D7. Analysis of the size of amplicons in each MSP subfamily revealed that FC27 had 4 alleles and 3D7 had 3 alleles (Table 4).

Table 4

Allelic frequency of the MSP 1 and MSP 2 genes in Aceh

\begin{tabular}{|c|c|c|c|c|c|c|c|}
\hline Gene & Allele Sub-Family & Number & $(\%)$ & Amplicon & Allele & $P$ value & $\mathrm{Cl} 95 \%$ \\
\hline \multirow[t]{6}{*}{ MSP1 } & K1 & 34 & 37.7 & $160-350 *$ & 3 & 0.02039 & $0.285-0.481$ \\
\hline & MAD20 & 42 & 46.7 & $160-500$ & 5 & 0.5271 & $0.367-0.569$ \\
\hline & R033 & 1 & 1.1 & \multirow[t]{4}{*}{$130-220$} & 2 & $<2.2 \mathrm{e}-16$ & $0.002-0.060$ \\
\hline & $\mathrm{K} 1+\mathrm{MAD} 20$ & 5 & 5.6 & & - & $<2.2 \mathrm{e}-16$ & $0.024-0.124$ \\
\hline & $\mathrm{K} 1+\mathrm{R} 033$ & 4 & 4.4 & & - & $<2.2 \mathrm{e}-16$ & $0.017-0.109$ \\
\hline & MAD20 + R033 & 4 & 4.4 & & - & $<2.2 \mathrm{e}-16$ & $0.017-0.109$ \\
\hline \multirow[t]{3}{*}{ MSP 2} & $\mathrm{FC} 27$ & 37 & 41.1 & $250-530$ & 4 & 0.02039 & $0.285-0.481$ \\
\hline & $3 \mathrm{D} 7$ & 34 & 37.7 & $100-450$ & 3 & 0.0917 & $0.315-0.514$ \\
\hline & $\mathrm{FC} 27+3 \mathrm{D} 7$ & 19 & 21.2 & - & - & $4.22 \mathrm{e}-08$ & $0.140-0.306$ \\
\hline
\end{tabular}

\section{Multiplicity of infection (MOI)}

Of the total 90 subjects analysed for the allelic subfamilies of MSP 1 and MSP 2, 13 subjects (14.4\%) were found to carry multiple allelic subfamilies infection of $M S P$ 1, whereas for $M S P 2,9$ subjects $(21.1 \%)$ were found. The MOIs for both MSP 1 and MSP 2 were 2.27 and 2.69, respectively. The MOI for MSP 2 was slightly higher than MSP 1 .

\section{Association of clinical manifestation with the MSP1 and MSP2 alleles subfamilies}

Analysis of $M S P 1$ and $M S P 2$ allelic subfamilies and each form of clinical manifestation and laboratory profiles revealed that liver function abnormal value was the only variable showing significant correlation with multiple allelic subfamilies of FC27 + 3D7 (OR: $0.13 ; 95 \% \mathrm{Cl} 0.03$ to $0.53, p<0.01$ ). All others clinical manifestations showed no significant correlation with allelic subfamilies of MSP 1 and MSP $2(p>0.05)$ (Tables 5-6). Based on the severity of clinical manifestation as classified by WHO [11] subjects carried the mixed allelic subfamilies of K1 and R033 of MSP 1 revealed a strong correlation with severe malaria $(p<0.05 ;$ odds ratio $=28.50 ; \mathrm{Cl} 95 \%=1.59-1532.3)($ Table 7$)$. Other alleles revealed either no association or insignificant $p$-value. 
Table 5

Association between clinical manifestation and MSP1 allelic subfamilies

\begin{tabular}{|c|c|c|c|c|c|c|c|c|}
\hline Clinical & Allele & Yes & & No & & $\begin{array}{l}P \\
\text { value }\end{array}$ & OR & $\mathrm{Cl} 95 \%$ \\
\hline manifestation & & $\mathrm{n}$ & $\%$ & $\mathrm{n}$ & $\%$ & & & \\
\hline \multirow[t]{6}{*}{ Shock } & K1 & 2 & 66.7 & 32 & 36.8 & - & - & - \\
\hline & MAD20 & 0 & 0 & 42 & 48.3 & - & - & - \\
\hline & R033 & 0 & 0 & 1 & 1.1 & - & - & - \\
\hline & $\begin{array}{l}\mathrm{K} 1+ \\
\text { MAD20 }\end{array}$ & 0 & 0 & 5 & 5.7 & - & - & - \\
\hline & $\mathrm{K} 1+\mathrm{R} 033$ & 1 & 33.3 & 3 & 3.5 & - & - & - \\
\hline & $\begin{array}{l}\text { MAD20 + } \\
\text { RO33 }\end{array}$ & 0 & 0 & 4 & 4.6 & - & - & - \\
\hline \multirow[t]{6}{*}{ Convulsion } & K1 & 2 & 100 & 32 & 36.4 & - & - & - \\
\hline & MAD20 & 0 & 0 & 42 & 47.7 & - & - & - \\
\hline & R033 & 0 & 0 & 1 & 1.1 & - & - & - \\
\hline & $\begin{array}{l}\mathrm{K} 1+ \\
\text { MAD20 }\end{array}$ & 0 & 0 & 5 & 5.7 & - & - & - \\
\hline & $\mathrm{K} 1+\mathrm{R} 033$ & 0 & 0 & 4 & 4.6 & - & - & - \\
\hline & $\begin{array}{l}\text { MAD20 + } \\
\text { R033 }\end{array}$ & 0 & 0 & 4 & 4.6 & - & - & - \\
\hline \multirow[t]{6}{*}{ Conscious disturbance } & K1 & 2 & 50 & 32 & 37.2 & - & - & - \\
\hline & MAD20 & 0 & 0 & 42 & 48.8 & - & - & - \\
\hline & $\mathrm{RO} 33$ & 0 & 0 & 1 & 1.2 & - & - & - \\
\hline & $\begin{array}{l}\mathrm{K} 1+ \\
\text { MAD20 }\end{array}$ & 0 & 0 & 5 & 5.8 & - & - & - \\
\hline & $\mathrm{K} 1+\mathrm{R} 033$ & 1 & 25 & 3 & 3.5 & - & - & - \\
\hline & $\begin{array}{l}\text { MAD20 + } \\
\text { R033 }\end{array}$ & 1 & 25 & 3 & 3.5 & - & - & - \\
\hline \multirow[t]{3}{*}{ Anemia } & K1 & 14 & 42.4 & 20 & 35.1 & 0.95 & 1.02 & $\begin{array}{l}0.3- \\
2.84\end{array}$ \\
\hline & MAD20 & 17 & 51.5 & 25 & 43.9 & - & - & - \\
\hline & R033 & 1 & 3 & 0 & 0 & - & - & - \\
\hline
\end{tabular}




\begin{tabular}{|c|c|c|c|c|c|c|c|c|}
\hline \multirow[t]{4}{*}{ Clinical } & Allele & \multicolumn{2}{|c|}{ Yes } & \multicolumn{2}{|l|}{ No } & \multirow{2}{*}{$\begin{array}{l}\mathbf{P} \\
\text { value } \\
0.37\end{array}$} & \multirow{2}{*}{$\begin{array}{l}\text { OR } \\
0.36\end{array}$} & \multirow{2}{*}{$\begin{array}{l}\text { Cl95\% } \\
0.01- \\
4.23\end{array}$} \\
\hline & $\begin{array}{l}\text { K1 }+ \\
\text { MAD20 }\end{array}$ & 1 & 3.1 & 4 & 7 & & & \\
\hline & $\mathrm{K} 1+\mathrm{R} 033$ & 0 & 0 & 4 & 7 & - & - & - \\
\hline & $\begin{array}{l}\text { MAD20 + } \\
\text { RO33 }\end{array}$ & 0 & 0 & 4 & 7 & - & - & - \\
\hline \multirow[t]{6}{*}{ Hemoglobinuria } & K1 & 9 & 50 & 25 & 34.7 & 0.18 & 2.16 & $\begin{array}{l}0.59- \\
8.30\end{array}$ \\
\hline & MAD20 & 6 & 33.3 & 36 & 50 & - & - & - \\
\hline & R033 & 0 & 0 & 1 & 1.3 & - & - & - \\
\hline & $\begin{array}{l}\mathrm{K} 1+ \\
\text { MAD20 }\end{array}$ & 1 & 5.6 & 4 & 5.6 & 0.73 & 1.50 & $\begin{array}{l}0.02- \\
19.04\end{array}$ \\
\hline & $\mathrm{K} 1+\mathrm{R} 033$ & 2 & 11.1 & 2 & 2.8 & 0.07 & 6 & $\begin{array}{l}0.34- \\
92.54\end{array}$ \\
\hline & $\begin{array}{l}\text { MAD20 + } \\
\text { RO33 }\end{array}$ & 0 & 0 & 4 & 5.6 & - & - & - \\
\hline \multirow[t]{6}{*}{ Splenomegaly } & K1 & 29 & 36.7 & 5 & 45.4 & 0.48 & 0.61 & $\begin{array}{l}0.11- \\
3.13\end{array}$ \\
\hline & MAD20 & 38 & 48.1 & 4 & 36.4 & - & - & - \\
\hline & R033 & 1 & 1.3 & 0 & 0 & - & - & - \\
\hline & $\begin{array}{l}\mathrm{K} 1+ \\
\mathrm{MAD} 20\end{array}$ & 5 & 6.3 & 0 & 0 & - & - & - \\
\hline & $\mathrm{K} 1+\mathrm{R} 033$ & 3 & 3.8 & 1 & 9.1 & 0.34 & 0.31 & $\begin{array}{l}0.01- \\
20.67\end{array}$ \\
\hline & $\begin{array}{l}\text { MAD20 + } \\
\text { R033 }\end{array}$ & 3 & 3.8 & 1 & 9.1 & 0.3 & 0.31 & $\begin{array}{l}0.01- \\
20.67\end{array}$ \\
\hline \multirow[t]{6}{*}{$\begin{array}{l}\text { Abnormality in the value of liver } \\
\text { function }\end{array}$} & K1 & 20 & 35.1 & 14 & 42.4 & 0.78 & 0.87 & $\begin{array}{l}0.31- \\
2.45\end{array}$ \\
\hline & MAD20 & 26 & 45.6 & 16 & 48.5 & - & - & - \\
\hline & R033 & 1 & 1.8 & 0 & 0 & - & - & - \\
\hline & $\begin{array}{l}\mathrm{K} 1+ \\
\text { MAD20 }\end{array}$ & 1 & 7 & 1 & 3 & 0.42 & 2.46 & $\begin{array}{l}0.21- \\
128.66\end{array}$ \\
\hline & $\mathrm{K} 1+\mathrm{R} 033$ & 4 & 7 & 0 & 0 & - & - & - \\
\hline & $\begin{array}{l}\text { MAD20 + } \\
\text { R033 }\end{array}$ & 2 & 3.5 & 2 & 6.1 & 0.64 & 0.61 & $\begin{array}{l}0.04- \\
9.37\end{array}$ \\
\hline
\end{tabular}




\begin{tabular}{|c|c|c|c|c|c|c|c|c|}
\hline Clinical & Allele & Yes & & No & & $\begin{array}{l}P \\
\text { value }\end{array}$ & OR & $\mathrm{Cl} 95 \%$ \\
\hline \multirow[t]{6}{*}{ Dyspnea } & K1 & 26 & 38.3 & 8 & 36.4 & 0.82 & 0.88 & $\begin{array}{l}0.26- \\
3.05\end{array}$ \\
\hline & MAD20 & 33 & 48.5 & 9 & 40.9 & - & - & - \\
\hline & R033 & 1 & 1.5 & 0 & 0 & - & - & - \\
\hline & $\begin{array}{l}\mathrm{K} 1+ \\
\mathrm{MAD} 20\end{array}$ & 2 & 2.9 & 3 & 13.7 & 0.06 & 0.18 & $\begin{array}{l}0.01- \\
1.92\end{array}$ \\
\hline & $\mathrm{K} 1+\mathrm{RO} 33$ & 3 & 4.4 & 1 & 4.5 & 0.86 & 0.81 & $\begin{array}{l}0.05- \\
47.66\end{array}$ \\
\hline & $\begin{array}{l}\text { MAD20 + } \\
\text { RO33 }\end{array}$ & 3 & 4.4 & 1 & 4.5 & 0.86 & 0.81 & $\begin{array}{l}0.05- \\
47.66\end{array}$ \\
\hline \multirow{6}{*}{$\begin{array}{l}\text { Abnormality in the value of } \\
\text { kidney function }\end{array}$} & K1 & 32 & 37.2 & 2 & 50 & - & - & - \\
\hline & MAD20 & 40 & 46.5 & 2 & 50 & - & - & - \\
\hline & R033 & 1 & 1.3 & 0 & 0 & - & - & - \\
\hline & $\begin{array}{l}\mathrm{K} 1+ \\
\mathrm{MAD} 20\end{array}$ & 5 & 5.8 & 0 & 0 & - & - & - \\
\hline & $\mathrm{K} 1+\mathrm{RO} 33$ & 4 & 4.6 & 0 & 0 & - & - & - \\
\hline & $\begin{array}{l}\text { MAD20 + } \\
\text { RO33 }\end{array}$ & 4 & 4.6 & 0 & 0 & - & - & - \\
\hline \multirow{6}{*}{$\begin{array}{l}\text { Fever } \\
(\geq 39.0 \otimes C)\end{array}$} & K1 & 23 & 44.2 & 11 & 28.9 & 0.22 & 1.84 & $\begin{array}{l}0.6- \\
5.66\end{array}$ \\
\hline & MAD20 & 17 & 32.7 & 25 & 65.8 & - & - & - \\
\hline & R033 & 1 & 1.9 & 0 & 0 & - & - & - \\
\hline & $\begin{array}{l}\mathrm{K} 1+ \\
\mathrm{MAD} 20\end{array}$ & 3 & 5.8 & 2 & 5.3 & 0.77 & 1.32 & $\begin{array}{l}0.13- \\
17.73\end{array}$ \\
\hline & $\mathrm{K} 1+\mathrm{RO} 33$ & 4 & 7.7 & 0 & 0 & - & - & - \\
\hline & $\begin{array}{l}\text { MAD20 + } \\
\text { R033 }\end{array}$ & 4 & 7.7 & 0 & 0 & - & - & - \\
\hline
\end{tabular}


Table 6

Association between clinical manifestation and MSP2 allelic subfamilies

\begin{tabular}{|c|c|c|c|c|c|c|c|c|}
\hline \multirow{2}{*}{$\begin{array}{l}\text { Clinical } \\
\text { manifestation }\end{array}$} & \multirow[t]{2}{*}{ Allele } & \multicolumn{2}{|c|}{ Yes } & \multicolumn{2}{|c|}{ No } & \multirow{2}{*}{$\begin{array}{l}\mathrm{P} \\
\text { value }\end{array}$} & \multirow[t]{2}{*}{ OR } & \multirow[t]{2}{*}{$\mathrm{Cl} 95 \%$} \\
\hline & & $\mathrm{n}$ & $\%$ & $\mathrm{n}$ & $\%$ & & & \\
\hline \multirow[t]{3}{*}{ Shock } & $3 D 7$ & 1 & 33.3 & 36 & 41.4 & - & - & - \\
\hline & $\mathrm{FC} 27$ & 2 & 66.7 & 32 & 36.8 & 0.50 & 2.25 & $\begin{array}{l}0.11- \\
136.35\end{array}$ \\
\hline & $\begin{array}{l}\mathrm{FC} 27+ \\
3 \mathrm{D} 7\end{array}$ & 0 & 0 & 19 & 21.8 & - & - & - \\
\hline \multirow[t]{3}{*}{ Convulsion } & 3D7 & 1 & 50 & 36 & 40.9 & - & - & - \\
\hline & $\mathrm{FC} 27$ & 1 & 50 & 33 & 37.5 & 0.95 & 1.09 & $\begin{array}{l}0.01- \\
87.97\end{array}$ \\
\hline & $\begin{array}{l}\mathrm{FC} 27+ \\
3 \mathrm{D} 7\end{array}$ & 0 & 0 & 19 & 21.6 & - & - & - \\
\hline \multirow[t]{3}{*}{ Conscious disturbance } & $3 D 7$ & 2 & 50 & 35 & 40.7 & - & - & - \\
\hline & $\mathrm{FC} 27$ & 1 & 25 & 33 & 38.4 & 0.60 & 0.53 & $\begin{array}{l}0.01- \\
87.97\end{array}$ \\
\hline & $\begin{array}{l}\mathrm{FC} 27+ \\
\text { 3D7 }\end{array}$ & 1 & 25 & 18 & 20.9 & 0.98 & 0.97 & $\begin{array}{l}0.01- \\
19.88\end{array}$ \\
\hline \multirow[t]{3}{*}{ Anemia } & $3 \mathrm{D} 7$ & 15 & 45.5 & 22 & 38.6 & - & - & - \\
\hline & $\mathrm{FC} 27$ & 10 & 30.3 & 24 & 41.2 & 0.32 & 0.61 & $\begin{array}{l}0.20- \\
1.82\end{array}$ \\
\hline & $\begin{array}{l}\mathrm{FC} 27+ \\
3 \mathrm{D} 7\end{array}$ & 8 & 24.2 & 11 & 19.3 & 0.91 & 1.06 & $\begin{array}{l}0.29- \\
3.75\end{array}$ \\
\hline \multirow[t]{3}{*}{ Hemoglobinuria } & $3 D 7$ & 5 & 27.8 & 32 & 44.5 & - & - & - \\
\hline & $\mathrm{FC} 27$ & 11 & 61.1 & 23 & 31.9 & 0.06 & 3.06 & $\begin{array}{l}0.82- \\
12.64\end{array}$ \\
\hline & $\begin{array}{l}\mathrm{FC} 27+ \\
3 \mathrm{D} 7\end{array}$ & 2 & 11.1 & 17 & 23.6 & 0.74 & 0.75 & $\begin{array}{l}0.06- \\
10 / 72\end{array}$ \\
\hline \multirow[t]{3}{*}{ Splenomegaly } & $3 \mathrm{D} 7$ & 32 & 40.5 & 5 & 45.4 & - & - & - \\
\hline & FC27 & 31 & 39.2 & 3 & 27.3 & 0.53 & 1.61 & $\begin{array}{l}0.28- \\
11.21\end{array}$ \\
\hline & $\begin{array}{l}\mathrm{FC} 27+ \\
3 \mathrm{D} 7\end{array}$ & 16 & 20.3 & 3 & 27.3 & 0.81 & 0.83 & $\begin{array}{l}0.14- \\
6.06\end{array}$ \\
\hline $\begin{array}{l}\text { Abnormality in the value of liver } \\
\text { function }\end{array}$ & $3 D 7$ & 27 & 47.4 & 10 & 30.3 & - & - & - \\
\hline
\end{tabular}




\begin{tabular}{|c|c|c|c|c|c|c|c|c|}
\hline \multirow[t]{3}{*}{ Clinical } & \multirow{2}{*}{$\begin{array}{l}\text { Allele } \\
\text { FC27 }\end{array}$} & \multicolumn{2}{|l|}{ Yes } & \multicolumn{2}{|l|}{ No } & \multirow{2}{*}{$\begin{array}{l}\mathbf{P} \\
\text { value } \\
0.95\end{array}$} & \multirow{2}{*}{$\begin{array}{l}\text { OR } \\
1.02\end{array}$} & \multirow{2}{*}{$\begin{array}{l}\text { Cl95\% } \\
0.31- \\
3.38\end{array}$} \\
\hline & & 25 & 43.8 & 9 & 27.3 & & & \\
\hline & $\begin{array}{l}\mathrm{FC} 27+ \\
\text { 3D7 }\end{array}$ & 5 & 8.8 & 14 & 42.4 & <. 01 * & 0.13 & $\begin{array}{l}0.03- \\
0.53\end{array}$ \\
\hline \multirow[t]{3}{*}{ Dyspnea } & $3 D 7$ & 27 & 39.7 & 10 & 45.4 & - & - & - \\
\hline & FC27 & 28 & 41.2 & 6 & 27.3 & 0.34 & 1.72 & $\begin{array}{l}0.48- \\
6.59\end{array}$ \\
\hline & $\begin{array}{l}\mathrm{FC} 27+ \\
3 \mathrm{D} 7\end{array}$ & 13 & 19.1 & 6 & 27.3 & 0.72 & 0.80 & $\begin{array}{l}0.20- \\
3.31\end{array}$ \\
\hline \multirow{3}{*}{$\begin{array}{l}\text { Abnormality in the value of kidney } \\
\text { function }\end{array}$} & $3 D 7$ & 35 & 40.7 & 2 & 50 & - & - & - \\
\hline & FC27 & 33 & 38.4 & 1 & 25 & 0.60 & 1.88 & $\begin{array}{l}0.09- \\
114.55\end{array}$ \\
\hline & $\begin{array}{l}\mathrm{FC} 27+ \\
3 \mathrm{D} 7\end{array}$ & 18 & 20.9 & 1 & 25 & 0.98 & 1.02 & $\begin{array}{l}0.05- \\
64.01\end{array}$ \\
\hline \multirow{3}{*}{$\begin{array}{l}\text { Fever } \\
(\geq 39.0 \otimes C)\end{array}$} & $3 D 7$ & 18 & 34.6 & 19 & 50 & - & - & - \\
\hline & FC27 & 24 & 46.2 & 10 & 26.3 & 0.06 & 2.53 & $\begin{array}{l}0.85- \\
7.62\end{array}$ \\
\hline & $\begin{array}{l}\mathrm{FC} 27+ \\
\text { 3D7 }\end{array}$ & 10 & 19.2 & 9 & 23.7 & 0.77 & 1.17 & $\begin{array}{l}0.33- \\
4.10\end{array}$ \\
\hline
\end{tabular}

Table 7

Association of malaria severity with the MSP 1 and MSP2 alleles

\begin{tabular}{|c|c|c|c|c|c|c|c|c|}
\hline \multirow[t]{2}{*}{ Gene } & \multirow[t]{2}{*}{ Allele } & \multicolumn{2}{|c|}{ Severe } & \multicolumn{2}{|c|}{ Mild } & \multirow[t]{2}{*}{$P$ value } & \multirow[t]{2}{*}{ OR } & \multirow[t]{2}{*}{$\mathrm{Cl} 95 \%$} \\
\hline & & $\mathrm{n}$ & $\%$ & $\mathrm{n}$ & $\%$ & & & \\
\hline \multirow[t]{6}{*}{ MSP1 } & K1 & 7 & 36.8 & 27 & 38 & 0.17 & 2.46 & $0.55-12.50$ \\
\hline & MAD20 & 4 & 21 & 38 & 53.6 & - & - & - \\
\hline & RO33 & 0 & 0 & 1 & 1.4 & - & - & - \\
\hline & $\mathrm{K} 1+\mathrm{MAD} 20$ & 1 & 5.4 & 4 & 5.6 & 0.47 & 2.37 & $0.03-33.59$ \\
\hline & $\mathrm{K} 1+\mathrm{RO} 33$ & 3 & 15.8 & 1 & 1.4 & $0.00 *$ & 28.50 & $1.59-15.32$ \\
\hline & MAD20 + R033 & 4 & 21 & 0 & 0 & - & - & - \\
\hline \multirow[t]{3}{*}{ MSP2 } & $3 D 7$ & 7 & 36.8 & 30 & 42.3 & - & - & - \\
\hline & FC27 & 11 & 57.9 & 23 & 32.4 & 0.19 & 2.04 & $0.6-7.22$ \\
\hline & $\mathrm{FC} 27+3 \mathrm{D} 7$ & 1 & 5.3 & 18 & 25.3 & 0.16 & 0.23 & $0.01-2.15$ \\
\hline
\end{tabular}




\section{Discussion}

Analysis of the clinical manifestation of the malaria cases admitted to the hospitals in Aceh revealed that the classical symptoms such as fever with chill is still the primary symptom experienced by the patients, followed by dyspnoea and spleen enlargement. Majority of the malaria cases are classified as mild, uncomplicated malaria but over $20 \%$ of which are severe according to WHO criteria [11]. The findings are in accordance with the report of the Ministry of Health where malaria in many parts of Aceh Province continues to decrease, making the risk to having malaria also diminishing and affect mainly adults who stay or travel to remaining endemic foci in the Province or other parts of the country [14]. This situation is completely different with the malaria cases found in eastern parts of the country where children are still the most vulnerable group and adults are usually asymptomatic $[15,16]$.

Analysis of the MOI based on the allelic diversity of MSP1 and MSP2 revealed a value of 2.27 and 2.67 for the MSP1 and MSP2 respectively. This finding is slightly higher than the MOI data from Myanmar [17] and Southwest Pacific [18] but lower than Thailand, Kenya and Burkina Faso [19-22]. The difference in $\mathrm{MOI}$ can be attributed to several factors such as differences in geographical areas, intensity of malaria transmission, and difference in age of study population and mean parasite density in the study population [23-25]. In our study, all subjects are adult with symptomatic malaria and therefore with a relatively higher parasite density. Several studies reported conflicting results in which the MOI correlates with ages, parasite density [25,26] and intensity of malaria transmission [27] but others studies failed to demonstrate this correlation $[28,29]$. The low $\mathrm{MOI}$ reported in our study might also be attributed to the decreasing malaria transmission intensity in Aceh, following the implementation of the malaria elimination program in the area. It is of interest to note that despite a significant reduction of malaria in the area, a challenge of zoonotic malaria is currently increasing [30].

Analysis on the genetic diversity profiles of $P$. falciparum with the malaria clinical manifestation may provide useful information about parasite characteristics to design specific intervention strategies targeting the virulence factors [31] as well as to the evaluation of drug efficacy [32]. To our knowledge, this study is the first study in Indonesia that provides information about genetic diversity of MSP 1 and MSP 2 alleles of Plasmodium falciparum among the hospitalized malaria cases. Analysis to determine the association between allelic subfamilies of the MSP 1 and MSP 2 with malaria severity revealed a strong association between mixed $M S P 1 \mathrm{~K} 1+\mathrm{R} 033$ with severe malaria. The findings is slightly different with that of Ariey et al [10] where K1 allele subfamily and the $D$ allele of vargene overexpression associated with severe malaria. Others findings reported a high proportion of subjects carrying the FC27 allele subfamily among the uncomplicated malaria patients [33]. This difference might be associated with the multifactorial nature of severe malaria with diverse clinical manifestation [2]. The difference in geographic setting, age of the subjects, and genetic background of the parasites and host certainly contribute substantial role. This finding is in accordance with the findings in previous studies in BoboDioulasso [34]. Another study has also investigated genetic diversity of $P$. falciparum isolates, which was conducted in Libreville, Gabon. In the study, extensive genetic polymorphism within MSP 1 allelic families (30 alleles identified) has been observed. This is consistent with the diversity found in Bakoumba (25 
alleles) in 1999, Senegal (33 alleles) in 1995, and in Mauritania (27 alleles) in 2010 [35, 36]. Our study on the distribution of MSP 2 allele subfamilies showed the presence of two allelic subtypes in the study area, which is similar to the results of study conducted by Kang et al in Myanmar where the geographical areas are alike. Their study also found only two allelic subtypes in Myanmar, which are the FC27 and 3D7. The difference between their study and our study is that the number of patients infected by mixed allelic subtypes is higher than patients affected by single infections; while our study has demonstrated contrasted finding where single infection, either by FC27 or 3D7 alleles is higher [37]. This study also evaluated each clinical manifestations and symptoms among patients with falciparum malaria in Aceh Province and found out association between liver function abnormal value with nixed allelic MSP2 infection. This finding has never been analysed in previous studies except for the severe malarial anaemia [33]. Despite different results found, a closer observation on the phenotypes deserve further exploration in the other geographic areas. We also acknowledge several limitation of this study such as the inadequate amount of sample size, difficulties to precisely estimate the allelic frequencies and genetic diversity due to the detection limit of the PCR technique used in the study. Alleles with short differences in length (less than $10 \mathrm{bp}$ ) might not be clearly distinguished.

\section{Conclusion}

Allelic subfamilies analysis of the MSP 1 and MSP2 genes among the hospitalized uncomplicated and severe malaria cases in Aceh have been analysed. Association between liver function abnormal value with the mixed allelic type of MSP 2 was observed. Mixed allelic infection of MSP $1 \mathrm{~K} 1$ and RO33 is strongly associated with severe malaria. Further study to explore more subjects in different geographic setting is recommended.

\section{Declarations}

\section{Ethics approval and consent to participate}

This study has been approved by the Medical and Health Research Ethic Committee, Faculty of Medicine Gajah Mada University, with reference No: KE/FK/173/EC, 19 February 2013.

\section{Consent for publication}

Not applicable.

\section{Availability of data and materials}

All relevant data are within the manuscript.

\section{Competing interests}

The authors declare that they have no conflict of interest. 


\section{Funding}

Samples collection in Aceh were supported by Research Grant from The Ministry of Research and Technology, Republic of Indonesia, through Faculty of Medicine, Syiah Kuala University. Molecular analysis was also supported by The Ministry of Research and Technology, Republic of Indonesia, through Eijkman Institute for Molecular Biology.

\section{Authors' contributions}

KFJ, HH, MRK, and TMZ performed samples collection and data analysis. KFZ, NRP, SSM, JH, IER, PBSA, and DS molecular assays, data analysis, and manuscript writing. KFJ, $S$ and DS designed the study and responsible for management and fund raising for this study. All authors read and approved the final manuscript.

\section{Acknowledgements}

The authors are grateful to individuals who participated in this study. The authors wish to thank staffs from the Faculty of Medicine Syiah Kuala University Aceh, Eijkman Institute for Molecular Biology Jakarta, professional staffs at Aceh Provincial Health Department, District Health Department Kota Banda Aceh, Sabang, Kota Lhokseumawe, Aceh Besar, Aceh Barat Daya, Nagan Raya, Aceh Barat, Aceh Jaya, Aceh Utara, Pidie Jaya, and Pidie, for the support, encouragement and helping for samples collection. Ferdyan Fuad helping for administration in study. This study is part of a KFJ dissertation for doctorate program at the Gajah Mada University.

\section{References}

1. Ministry of Health. Republic of Indonesia. Buku saku pedoman pengobatan malaria di Indonesia. 2017.

2. Miller LH, Baruch DI, Marsh K, Doumbo OK. The pathogenic basis of malaria. Nature. 2002;415:6739.

3. Holder AA, Blackman MJ, Burghaus PA, Chappel JA, Ling IT, McCallum Deighton N, et al. A malaria merozoite surface protein (MSP1)-structure, processing and function. Mem Inst Oswaldo Cruz. 1992;87:37-42.

4. Apio B, Nalunkuma A, Okello D, Riley E, Egwang TG. Human IgG subclass antibodies to the 19 kilodalton carboxy terminal fragment of Plasmodium falciparum merozoite surface protein 1 (MSP1(19)) and predominance of the MAD20 allelic type of MSP1 in Uganda. East Afr Med J. 2000;77:189-93.

5. Woehlbier U, Epp C, Kauth CW, Lutz R, Long CA, Coulibaly B, et al. Analysis of antibodies directed against merozoite surface protein 1 of the human malaria parasite Plasmodium falciparum. Infect Immun. 2006;74:1313-22. 
6. Takala S, Branch O, Escalante AA, Kariuki S, Wootton J, Lal AA. Evidence for intragenic recombination in Plasmodium falciparum: identification of a novel allele family in block 2 of merozoite surface protein-1: Asembo Bay Area Cohort Project XIV. Mol Biochem Parasitol. 2002;125:163-71.

7. Takala SL, Escalante AA, Branch OH, Kariuki S, Biswas S, Chaiyaroj SC. Genetic diversity in the Block 2 region of the merozoite surface protein 1 (MSP-1) of Plasmodium falciparum: additional complexity and selection and convergence in fragment size polymorphism. Infect Genet Evol. 2006;6:417-24.

8. Ferreira MU, Hartl DL. Plasmodium falciparum: worldwide sequence diversity and evolution of the malaria vaccine candidate merozoite surface protein-2 (MSP-2). Exp Parasitol, 2007;11532-40.

9. Mohammed H, Mindaye T, Belayneh M, Kassa M, Assefa A, Tadesse M, et al. Genetic diversity of Plasmodium falciparum isolates based on MSP-1 and MSP-2 genes from Kolla-Shele area, Arbaminch Zuria District, southwest Ethiopia. Malar J. 2015;14:73.

10. Ariey F, Hommel D, Le Scanf C, Duchemin JB, Peneau C, Hulin A. Association of severe malaria with a specific Plasmodium falciparum genotype in French Guiana. J Infect Dis. 2001;15:237-41.

11. WHO. 2015. Guidelines for the treatment of malaria. 2nd edition. Geneva: WHO Library Cataloguing in Publication Data.

12. Wooden J, Kyes S, Sibley CH. PCR and strain identification in Plasmodium falciparum. Parasitol Today. 1993;9:303-5.

13. Methods in Malaria Research: Genotyping of Plasmodium falciparum parasites by PCR: msp1, msp2,and glurp, by Georges Snounou and Anna Färnert. ed. Inger Ljungström, Hedvig Perlmann, Martha Schlichtherle, Artur Scherf, Mats Wahlgren. 4. ed. Malaria Research and Reference Reagent Resource Center (MR4). 2008;p. 221 - 25.

14. Asih PBS, Rozi IE, Herdiana, Pratama NR, Hidayati AP, Marantina SS, et al. The baseline distribution of malaria in the initial phase of elimination in Sabang Municipality, Aceh Province, Indonesia. Malar J. 2012;11:291.

15. Syafruddin D, Chan, Asih P, Sekartuti, Dewi RM, Coutrier F, et al. Seasonal prevalence of malaria in West Sumba district, Indonesia. Malar J. 2009;9:8.

16. Syafruddin D, Bangs MJ, Sidik D, Elyazar I, Asih PBS, Chan K, et al. Impact of a Spatial Repellent on Malaria Incidence in Two Villages in Sumba, Indonesia. Am J Trop Med Hyg. 2014;91(6):1079-87.

17. Than NS, Wu Y, Tun MW, Xu X, Hu Y, Ruan Y, et al. Genetic diversity ofPlasmodium falciparumpopulations in southeast and western Myanmar. Paras Vect. 2017;10:322.

18. Cristian K, Waltmann A, Ome-Kaius M, Robinson LJ, Mueller I. Multiplicity of Infection Is a Poor Predictor of Village-Level Plasmodium vivax and P. falciparum Population Prevalence in the Southwest Pacific. Open Forum Infect Dis, 2018.

19. Abdoulie OT, Mobegi VA, Wamunyokoli F, Herren JK. Diversity and Multiplicity of $P$. falciparum infections among asymptomatic school children in Mbita, Western Kenya. Nature Res. 2020;10:5924. 
20. Olasehinde GI, Yah CS, Singh R, Olusola OO, Ajayi AA, Valecha N, et al. Genetic diversity of Plasmodium falciparum field isolates from southwestern Nigeria. African Health Sciences. 2012;12:3.

21. Tepanata P, Arnathau C, Durand P, Kanchanakhan N, Siripoon N, Suegorn A, et al. Genetic diversity and population structure of Plasmodium falciparum in Thailand, a low transmission country. Malar J. 2009;8:155.

22. Kanungnit C, Sukaram R, Prompan Y, Dornae A. Genetic diversity of the msp-1, msp-2, and glurp genes of Plasmodium falciparum isolates along the Thai-Myanmar borders. Asian Pac J Trop Biomed. 2014;4(8):598-602.

23. Issiaka S, Nébié I, Ouédraogo A, Gansane A, Diarra A, Tiono AB, et al. Plasmodium falciparum genotypes diversity in symptomatic malaria of children living in an urban and a rural setting in Burkina Faso. Malar J. 2009;8:135.

24. Hamid MM, Mohammed SB, El Hassan IM. Genetic diversity of Plasmodium falciparum field isolates in Central Sudan inferred by PCR genotyping of merozoite surface protein 1 and 2. N Am J Med Sci. 2013;5:95-101.

25. Konate L, Zwetyenga J, Rogier C, Bischoff E, Fontenille D, Tall A, et al. Variation of Plasmodium falciparum msp1 block 2 and msp2 allele prevalence and of infection complexity in two neigh bouring Senegalese villages with different transmission conditions. Trans R Soc Trop Med Hyg. 1999;93:21-8.

26. Vafa M, Troye-Blomberg M, Anchang J, Garcia A, Migot-Nabias F. Multiplicity of Plasmodium falciparum infection in asymptomatic children in Senegal: relation to transmission, age and erythrocyte variants. Malar J. 2008;7:17.

27. Slater M, Kiggundu M, Dokomajilar C, Kamya MR, Bakyaita N, Talisuna A, et al. Distinguishing recrudescences from new infections in antimalarial clinical trials: major impact of interpretation of genotyping results on estimates of drug efficacy. Am J Trop Med Hyg. 2005;73:256-62.

28. Bendixen M, Msangeni HA, Pedersen BV, Shayo D, Bodker R. Diversity of Plasmodium falciparum populations and complexity of infections in relation to transmission intensity and host age: a study from the Usambara Mountains, Tanzania. Trans R Soc Trop Med Hyg. 2001;95:143-8.

29. Basco LK, Ringwald P. Molecular epidemiology of malaria in Yaounde,Cameroon. VIII. Multiple Plasmodium falciparum infections in symptomatic patients. Am J Trop Med Hyg. 2001;65:798-803.

30. Issifou S, Ndjikou S, Sanni A, Lekoulou F, Ntoumi F. No influence of the transmission season on genetic diversity and complexity of infections in Plasmodium falciparum isolates from Benin. Afr $\mathrm{J}$ Med Med Sci. 2001;30:17-20.

31. Coutrier FN, Tirta YK, Cotter C, Zarlinda I, González IJ, Schwartz A, et al. Laboratory challenges of Plasmodium species identification in Aceh Province, Indonesia, a malaria elimination setting with newly discovered $P$. knowlesi. PLoS Negl Trop Dis, 2018:12(11).

32. Snounou G, Viriyakosol S, Jarra W, Thaithong S, Brown KN. Identification of the four human malaria parasite species in field samples by the polymerase chain reaction and detection of a high 
prevalence of mixed infections. Mol Biochem Parasitol. 1993;58:283-92.

33. Ishraga EA, ElGhazali G, A-Elgadir TME, Hamad AA, Babiker HA, Elbashir MI, Giha HA. Allelic polymorphism of MSP2 gene in severe P. falciparum malaria in an area of low and seasonal transmission. Parasitol Res. 2007;102:29-34.

34. Bazié T, Zongo I, Yerbanga RS, Nikiéma F, Neya C, Taho LK, et al. Plasmodium falciparum msp1 and msp2 genetic diversity and allele frequencies in parasites isolated from symptomatic malaria patients in Bobo-Dioulasso, Burkina Faso. Parasit Vectors. 2018;11:323.

35. Durand R, Ariey F, Cojean S, Fontanet A, Ranaivo L, Ranarivelo LA, et al. Analysis of circulating populations of Plasmodium falciparum in mild and severe malaria in two different epidemiological patterns in Madagascar. Trop Med Int Health. 2008;13:1392-9.

36. Konaté L, Zwetyenga J, Rogier C, Bischoff E, Fontenille D, Tall A, et al. Variation of Plasmodium falciparum msp1 block 2 and msp2 allele prevalence and of infection complexity in two neighbouring Senegalese villages with different transmission conditions. Trans R Soc Trop Med Hyg. 1999;93:21-8.

37. Amodu OK, Oyedeji SI, Ntoumi F, Orimadegun AE, Gbadegesin RA, Olumese PE, et al. Complexity of the msp2 locus and the severity of childhood malaria, in south-western Nigeria. Ann Trop Med Parasitol. 2008;102:95-110.

\section{Figures}




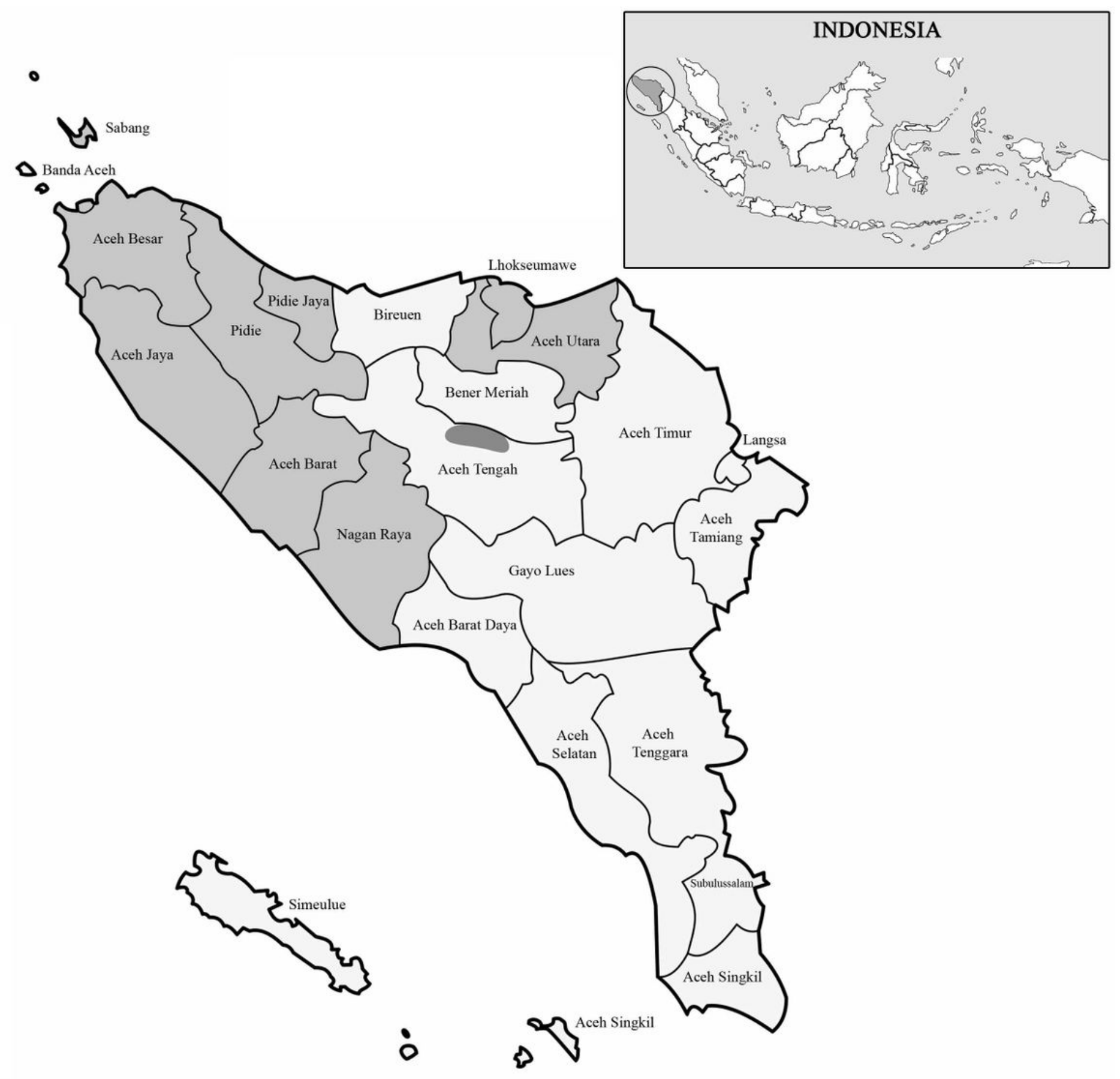

Figure 1

Study Sites in Aceh; Kota Banda Aceh, Sabang, Kota Lhokseumawe, Aceh Besar, Aceh Barat Daya, Nagan Raya, Aceh Barat, Aceh Jaya, Aceh Utara, Pidie Jaya, and Pidie 


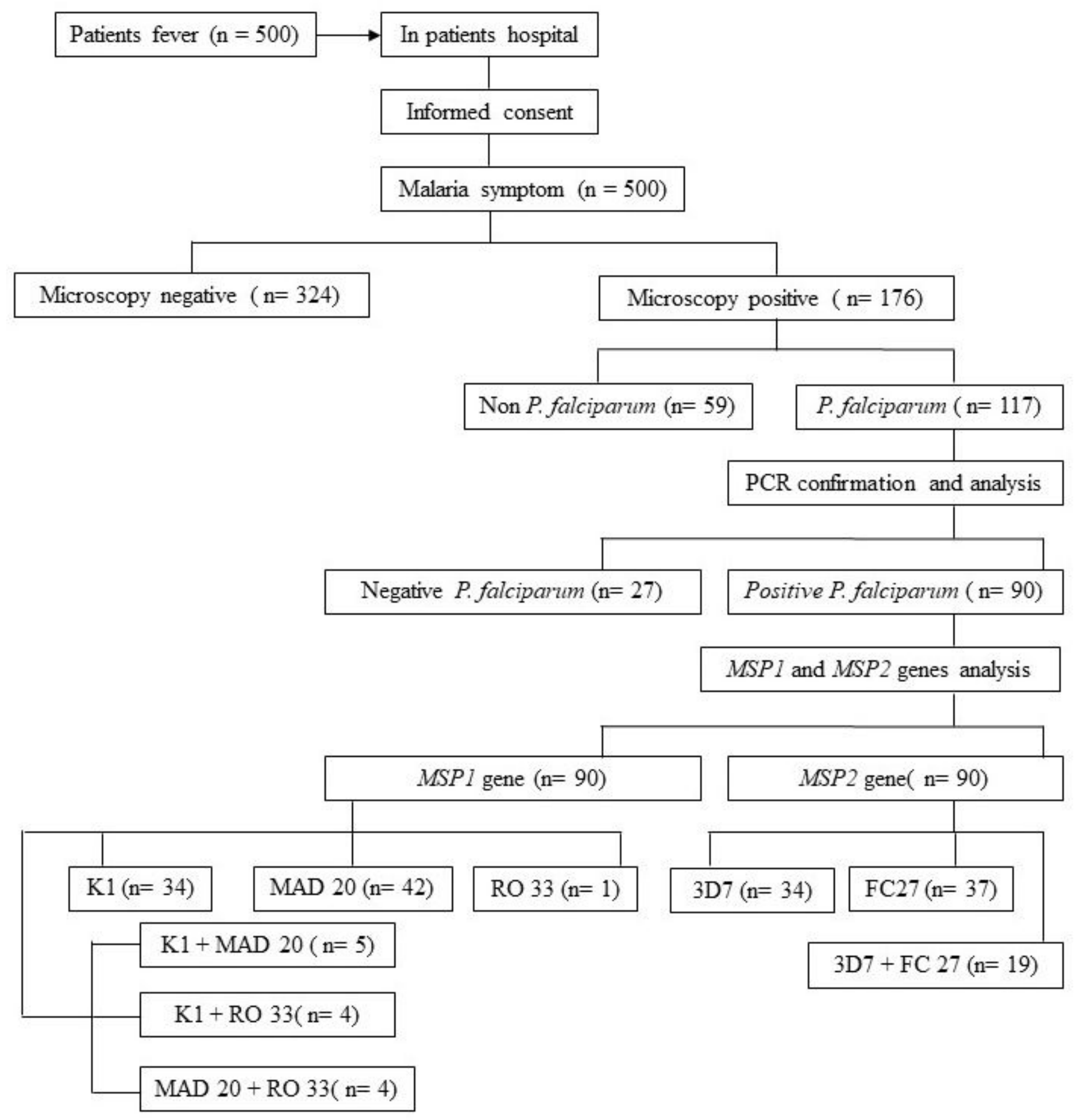

Figure 2

Study Flow Chart Samples Collection 